\title{
دور مؤسسات رياض الأطفال في تنمية الخيال والابداع العلمى لدى أطفالها (تصور مقتزح)
}

\section{شيرين صبم الطرسلى عوض على}

المقدمة:

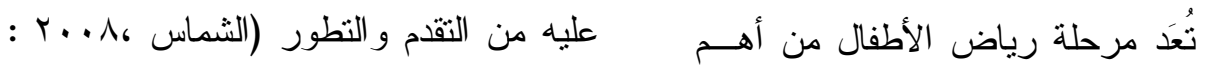

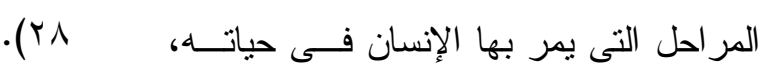

ويعتبر الخيال هام جدا للأطفال فهـو

حيث أنها تساهم فى تكوين شخصية الطفـلـل

يشغل حيزاً واسعاً فى نشاط الأطفال العقلى،

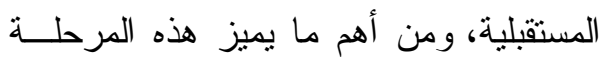

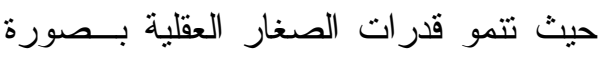

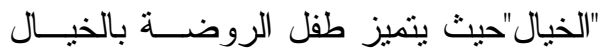

مستمرة، ولتربية الخيال عند الأطفال أهميــة

الو اسع الذى يحتاج إلى التدعيم من المحيطين

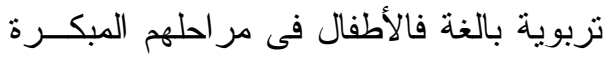

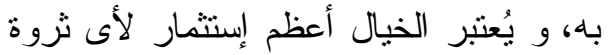

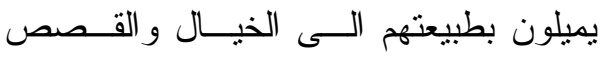
بشرية داخل أى مجتمع عصرى، فهو السبيل

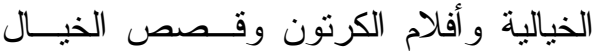

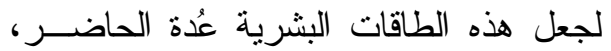

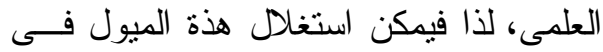
وقادة المستقبل ، وصانعوا الحضارة، و التقدم

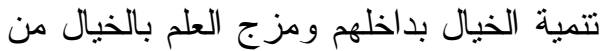
العلمى . العمان. أجل تتمية قدر اتهم على الإبـــاع والإبتكــار

وحيث أن الأطفال هم رجـال الغـــ، و التخيل، حيث ان الخيال هو مكون أساسـى الإلى الإنس

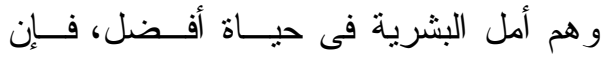

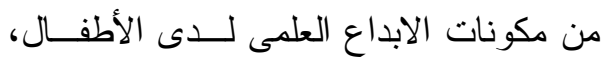

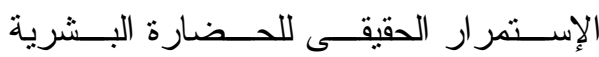

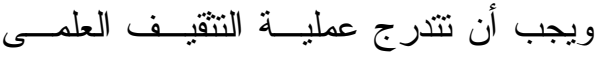
وتطوير ها يعتمد على بناء هؤلاء الأطفــال،

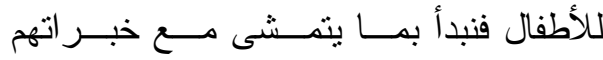

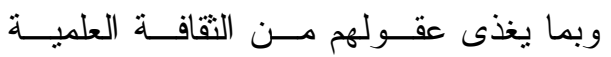

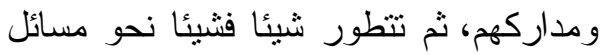

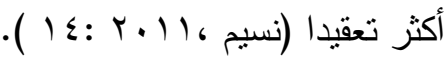
الموضوعية التى كانت وما زالت تسهم بدور كبير فى إثارة الخيال الإنسانى وتدفعة إلـى لـى لئى إن العصر الذى نعيش فيه هو عصر

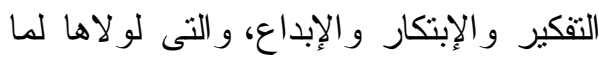

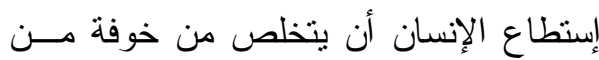

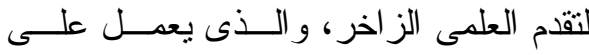
الطبيعة ومظاهر ها وينطلق إلى المكتهـثنات ستبعاد أياً من المجتمعات التى تتسم بالكسل و المخترعات التى أوصلت البشرية لما هـى الفى لكئ 
من القدرة على توظيف مفردات العصر فى

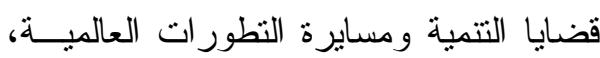
وتأتى أهمية مؤسسات رياض الأطفال فـى

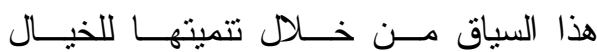

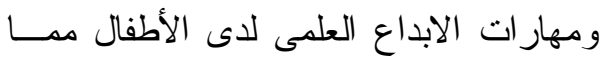
يساهم فى إعداد وتربية علماء المستقبل. وتُعد مؤسسة رياض الأطفــال مــن المؤسسات التربوية الهامة التى تتولى الطفل

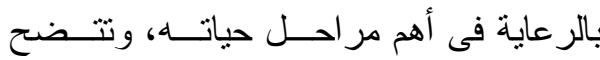

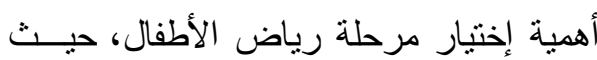

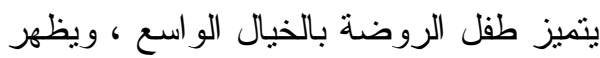

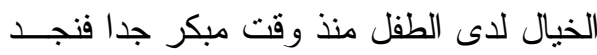
الطفل يعطى صفات الكــائن الحـى على لـى لـى الجماد، ويعلق على الموضوعات المختلفـــة فى البيئة المحبطة باستخدام كلمات من وحى خيالة وقد بصف صورة ويعطى لها تفاصيل

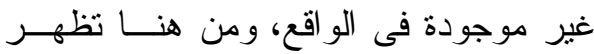

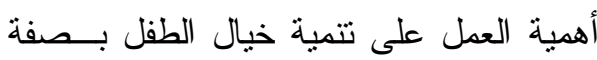
عامة و الذى يؤدى إلى ابداعه العلمى بــصفة خاصة (محمد ، با •r : ب ). كما يلاحظ تزايُـــ إهتمــام الــدول المتقدمة بنشر الثقافة العلمية ومحو الأُمية العلميه بين أبنائها: حيث قامت بإعداد العديد من برامج تطوير مناهج العلوم ومن أمنلنها

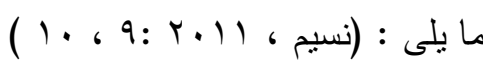

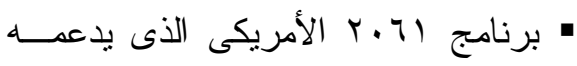

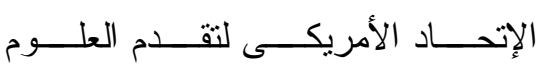

ينشأ ويظهر هذا التذفق العلمى إلا على أيدى

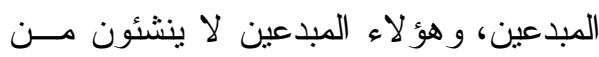

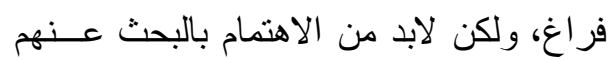

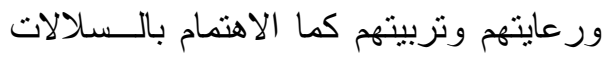

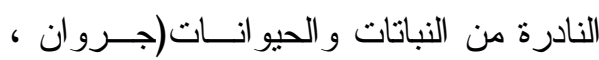

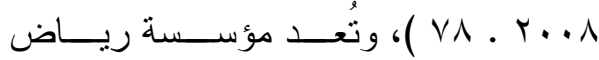
الأطفال لها الدور الأخطر فى تتشئة ورعاية

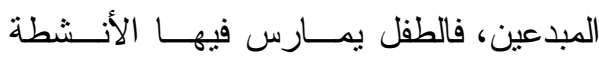

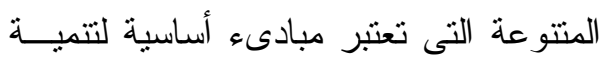

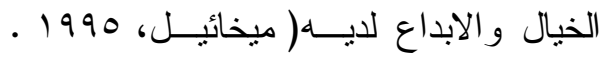
ونظر الأن الأطفال هم حجر الأساس

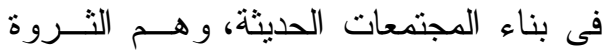

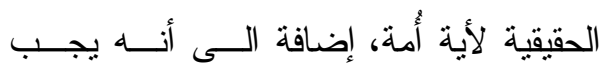

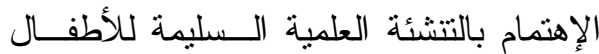
لأنهم عدتتا للمستقبل وبالتالى عبور الفجــوة

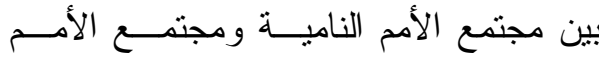
المتقدمة تحاول الدراسة الحالية التعرف على الافي دور مؤسسات رياض الأطفال فــى تتميـــة

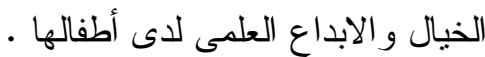

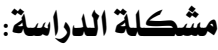

إن عصر المعلوماتية الــذى نعيـشة

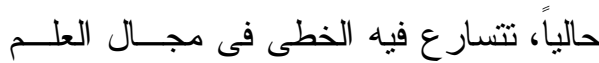

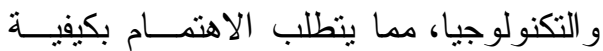
معايشة الحياه فى عالم الغد،وتهيئة الأطفال

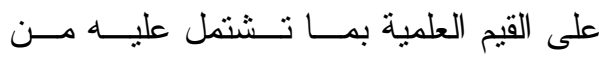
عناصر الخيال ومهار ات الابداع، مما يمكنهم 


$$
\begin{aligned}
& \text { - ما التصور المقترح لتفعيل دور مؤسسات } \\
& \text { رياض الأطفال فى تتمية الخيال و الابداع }
\end{aligned}
$$

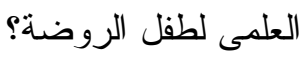

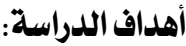

$$
\begin{aligned}
& \text { تهدف الدراسة الحاليه إلــى وضــع } \\
& \text { تصور مقترح لتفعيل الدور الذى ينبغـى أن }
\end{aligned}
$$

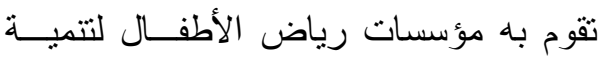

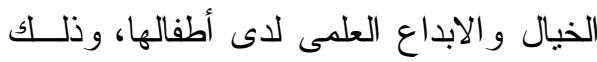

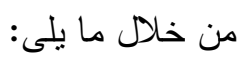

$$
\begin{aligned}
& \text { 1- التعرف على الإطار المفاهيمى للخيال } \\
& \text { و الابداع العلمى . } \\
& \text { Y- بيان معــالم دور مؤسـسـات ريــاض }
\end{aligned}
$$

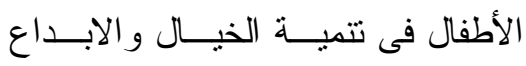

$$
\begin{aligned}
& \text { العلمى لدى أطفالها } \\
& \text { r- التعرف على الإعتبار ات التى ينبغـى ألى أنى }
\end{aligned}
$$

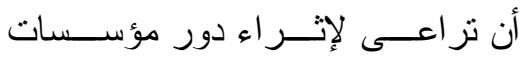

$$
\begin{aligned}
& \text { رياض الأطفال لتتمية الخيال و الابداع لإن دؤن } \\
& \text { العلمى لدى أطفالها . الداصن }
\end{aligned}
$$

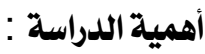

$$
\begin{aligned}
& \text { تتضـح أهمية الدراســـة مــن أهميــة }
\end{aligned}
$$

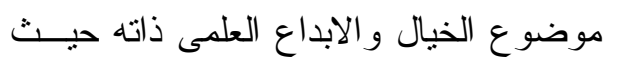

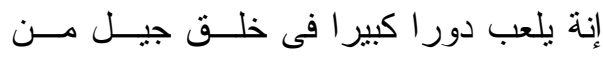

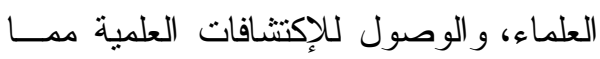

$$
\begin{aligned}
& \text { يساعد على تقدم الوطن } \\
& \text { وتسهم الدراسة فى تحقيق الجوانب التالية: }
\end{aligned}
$$

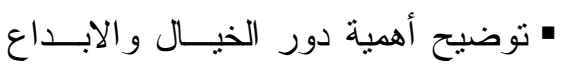

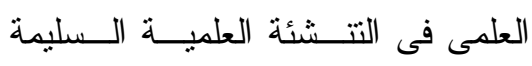

\section{American Association}

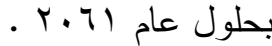

$$
\begin{aligned}
& \text { المختر عات العلميه للأطفال. } \\
& \text { العلمى لدى أطفال الروضة؟ }
\end{aligned}
$$

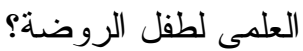


المعلمات الأنشطة و الألعاب التى تعمل على إثارة خيــال الأطفــال و اكــــابهم المفــــاهيم

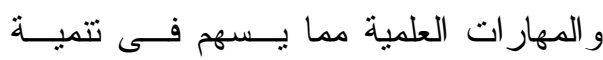
قدر اتهم الابداعية العلمية و الخيالية.

\section{(الغيال imagination : يعـرف (}

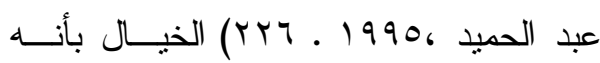
قدرة عقلية نشطة تعمل على تكوين الــصور

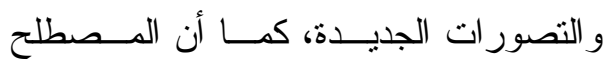
يتضمن عمليات الادج و التركيــب و واعـادة تركيب الذاكرة الخاصة بالخبر ات الماضـــية، وكذللك الصور التى تم تكوينها وتتكيلها أثناء

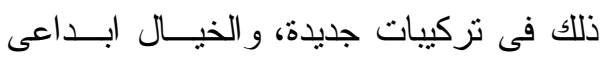
بنائى يتضمن الكثير من عمليــات التتظــيم العقلية.

\section{ويمكن تعريف الخيال لطقل الروضة}

فى الاراسة الحالية بأنه: قدرة عقلية فطرية

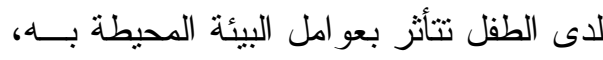

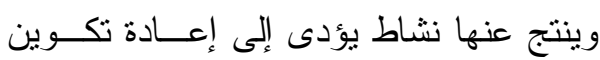

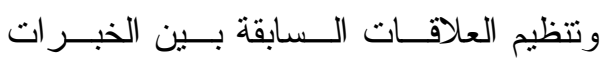
التز اكمية ويعيد صباغتها في شكل علاة لــات جديدة تُكون صور ذهنية مبتكرة لدى الطفل، ونل،

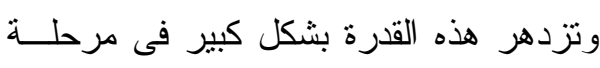

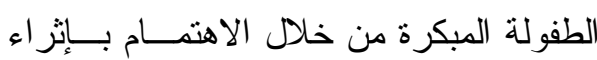
الخبر ات المقدمة للطفل لتتمية هـــذه القــدرة

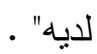

الابداع creative : تعرفـــه نايفــة

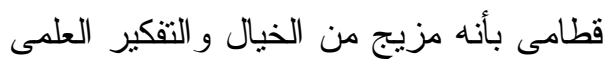

للأطفال و اكــــابهم المفـــاهيم العلميـــة ومهار ات التفكير العلمى . • توجية أنظار المتخصصين فى التربيـــة إلى ضرورة الإهتمام بالخيال و الابداع

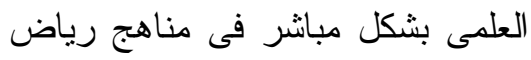

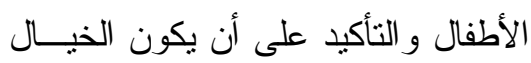

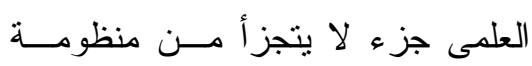

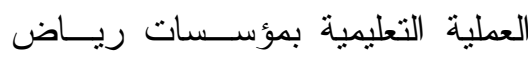

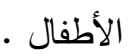
• توجيــة أنظــــار مــصمى الـــدورات التدريبية لمعلمــات ريــاض الأطفــال بضرورة تـــوفير الــدورات التنريبيـــة

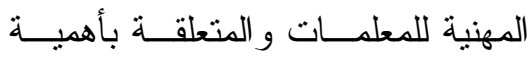

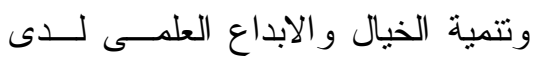

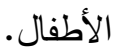

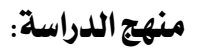
تستخدم الار اســـة الحاليــة المــنهج الوصفى، حيث التعرف على ملامح الــدور الذى تقوم به رياض الأطفال لتتمية الخيــال

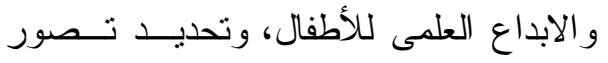

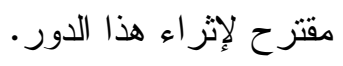

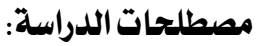

\section{ريــاض الأطفــال kindergarten}

وتعرفها الدراسة الحالية بأنهــا: مؤسـسات الحسات تربوية تعليمية حكومية، يلتحق بها الأطفــال

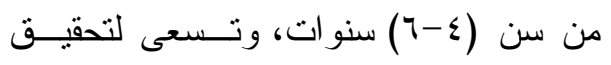

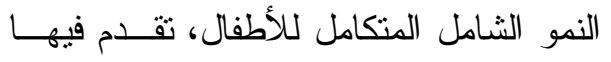


- ترنبط التزكيبات الجديدة التى ينت بناءها

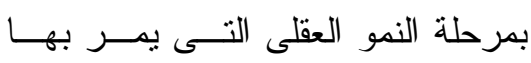

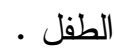

- إن تجهيز و واعداد عقل الطفـل للخيــال

والابداع العلمى يبدأ منذ مرحلة رياض

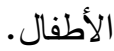

- إن الخيال والابداع العلمـى عمليــات

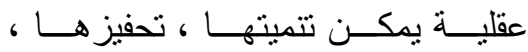

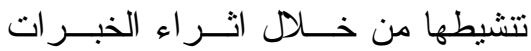

المقدمة للطفل بما يتتاسب مع المرحلة

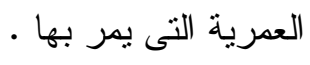

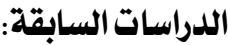

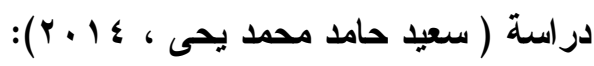

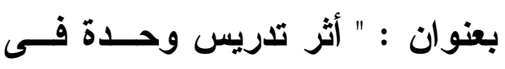

العلوم باستخدام الخيال العلمى إلكترونياً فى ولى تنمية مهارات التفكير الابداعى والدافعيـة

للإججاز لاى طلاب الصف الأول متوسط"

هدفت الدراسة إلى وضـــع تــصور

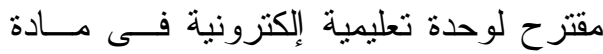

العلوم باستخدام الخيال العلمى للصف الأول

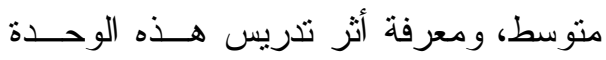

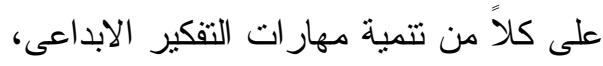

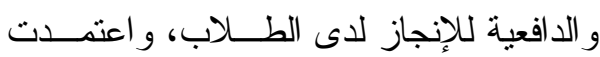

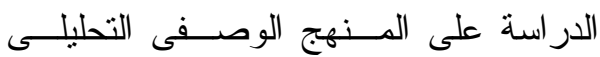

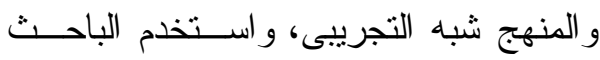

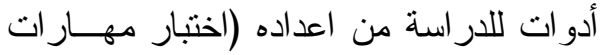

التفكير الابداعى ، مقياس الدافعية للإنجاز)،
لتطوير فكرة قديمة أو لإيجاد فكــــة جديــــة مهما كانت الفكرة صغيرة ينتج عنها إنتـاج

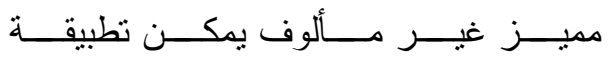

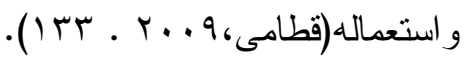

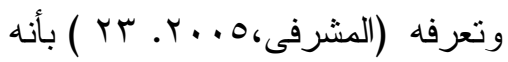
قدرة عقلية موجودة عند كل فــرد وبنـسبة معينة تختلف مــن واحــــ لآخـر، و وابــداع الصغير يكون جديداً بالنسبة إليه حتى لو كان

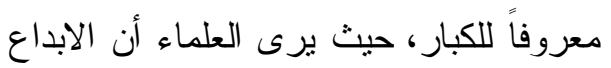
الحقيقى للانسان الناضج هو نتــــاج لعمليــة

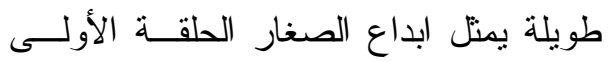
منها.

\section{ومما سبق يمكن تعريف الخيـال و}

الابداع العلمى لطفل الروضة فى الارســــة الحالية بأته: نشاط عقلى منظم، يُمكِن الطفل

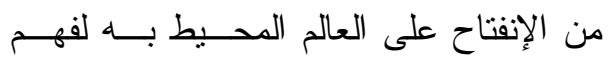

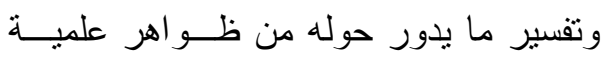

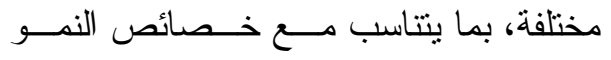
العقلى و المعرفى لمرحلة الطفولة المبكــــة بـان بحيث يكون مهيأ للوصول إلى تر اكيب ذهنية

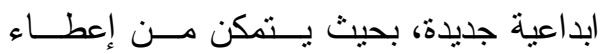

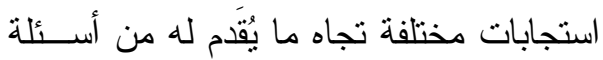
مفتوحة حول حياة الإنسان، ما يحيط به مسنـ مظاهر الطبيعة و البيئة المحيطة.

$$
\text { ويمكن تحليل التعريف الاجرائى فيما يلى: }
$$$$
\text { • إن الخيال هـــو القــدرة علــى انتــاج }
$$

$$
\text { تصور ات جديدة. }
$$


وتوصلت نتائج الدر اسة إلى وجــــد

فرق ذى دلالة إحــصائية بـين منوســطى

درجات تلامبذ المجموعة التجريبية وتلاميــذ

المجموعة الــضابطة لــصالح المجموعــة

التجريبية، حيث نثير النتائج فى مجملها إلى

فعالية البرنامج القائم على قــصص الخيــال

العلمى فى تتمية التعبير الكتابى الإبـــداعى،

حيث كان لقصص الخيال العلمى التى وفرها البرنامج دور كبير فى تنشيط خيالهم، مدـــا

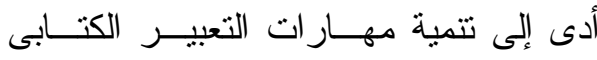
الإببداعى لديهم.

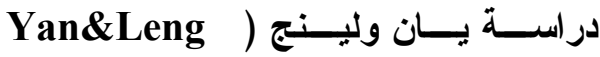
$:(, 2005$

بعنوان " التحقق من العلاقـــة بـين

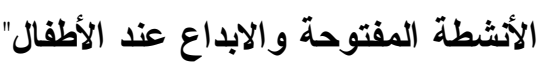
هدفت الدراسة إلـى التحقــق مــن

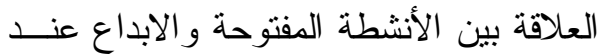
الأطفال، و اعتمدت على المنهج التجريبـى، وتكونت عينة الدر اسة مسـن ثلاتــة فــصول للتمهيـــدى نــــتخدم الأنــشطة المفتوحــــة بدرجة عالية ومتوسطة وقليلة، وتم استخدام

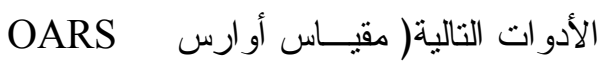
من تصميم الباحث، احتبار تور انس للتفكيـر

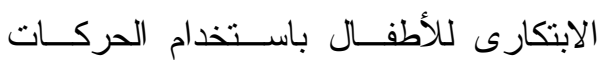

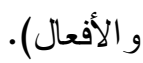

وتوصلت الدر استة إلى أن اســتخدام الأنشطة المفتوحة مع الأطفال أدى إلى نتائج
وتكونت عينة الدراسة من (بآ) طالباً مسن طلاب الصف الأول منوسط بـــإرارة بيــشة التعليمية بالمملكة العربية الـسعودية، وتــم

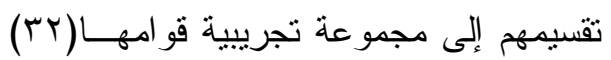
طالب، ومجموعــة ضـــابطة قو امهـــا (. ب)

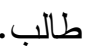
وتوصلت نتائج الدراســـة إلــى أن تدريس العلوم باســتخدام الخيــال العلمــى إلكترونياً قد حقق الفعالية المقبولة تزبوياً فى

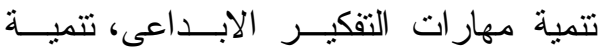
الدافعية للإنجاز لدى المجموعة التجريبية.

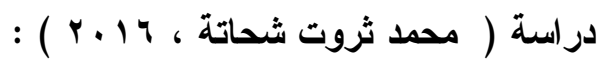
بعنوان: "فعالية برنامـج مقترح قائم على قصص الخيــال العلمــى فــى تنميــة مهارات التعبيز الكتابى الإبداعى لاى تلاميذ الصف الأول الإعدادى .

هدفت الدر اسة إلى التعرف على مدى فعالية البرنامج المقترح القائم على قـصص الخيال العلمى فى تتميـــة مهــــار ات التعبيــر الكتابى الإبداعى لدى تلاميذ الــصف الأول الإعدادى، و اعتمدت الدراسة علــى المــنهـج الوصفى التحليلى، و المنهج شبة التجريبـى، و اقتصر البحث على عينة من نلاميذ الصف الأول الإعدادى مــن مدرســتين مختلفتــين إحداهما مجمو عة تجريبية تدرس باسـتخدام البرنامج المقترح و الأخرى مجموعة ضابطة تدرس بالطريقة المعتادة. 
الأطفال، حيث اتضـح أن القـصص العلميــة

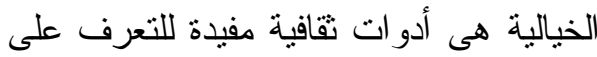

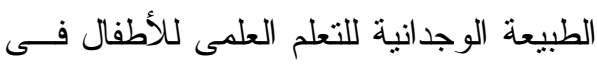

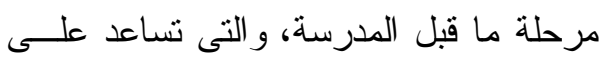
تتمية ابداعهم وخيالهم العلمى. توله

\section{تعليق على الدراسات السابقة:}

تلفق معظم الدراسات الــسابقة مــع

الدراسة الحالية فى التأكيد على أهمية الخيال

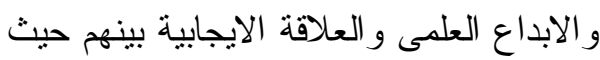

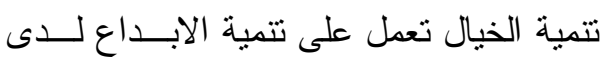
الأطفال ، وكذلك التأكيد على أهمية استخدام قصص الخيال العلمى و الأنشطة المفتوحة فى الهي

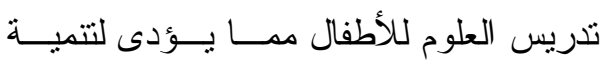

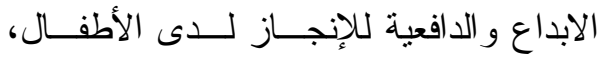

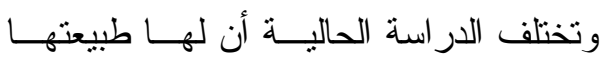

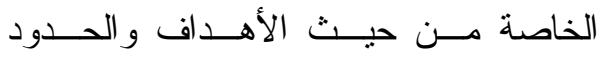

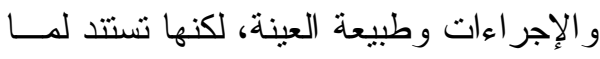
توصلت إليه الدراســات الــسابقة ( نظريــاً

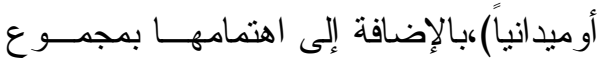

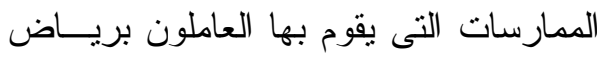
الأطفال ، وما يتم تقديمة من أنشطة مختلفـــة

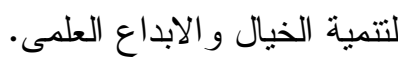
الإطار النظرى للدراسة تُعد مرحلة الطفولة مـن أخــصب

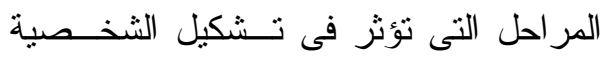
وتكوينها، فهى تمنل إطار اً تربوياً وتعليميــاً يعمل على تطوير الأطفال فى جميع النواحى تئ
ايجابية بالنسبة لمستوى التفكيــر الابــــاعى، بالإضافة إلى التحسن الملحوظ فى القــدرات

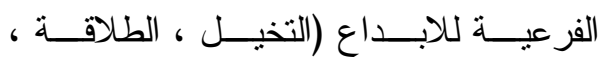
الأصالة). در اسة ( فلير ، Fleer,2013 ) بعنوان: " الخيال الوجدانى في تعلــيم العلوم: تحديد الطبيعة الوجدانية للتعلم العلمي و التكنولوجي للأطفال الصغار" هدفت الدراسة إلى التعـرف عانـى

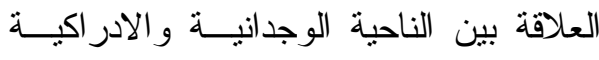

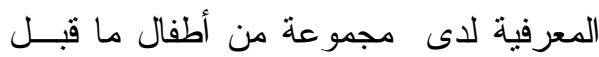

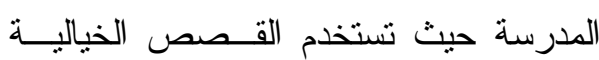
و التمثيل كعنصر ثقافى يعمل كإطار للــتعلم

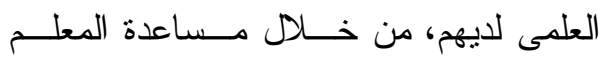

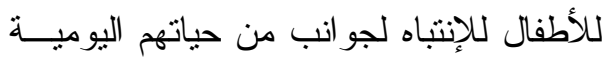
كثكل من أثنكال الملاحظة العلمية، وتكونت

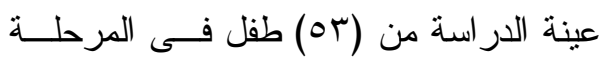
العمرية من (r-§)سنوات فى مركز للأطفال

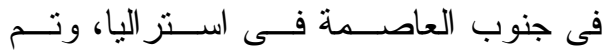

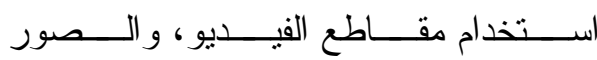
الفوتو غر افية، و الملاحظات الحقلية كـأدوات لللار اسة. وتوصلت نتائج الدراســة إلـى أن

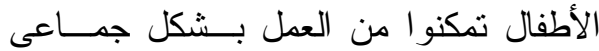

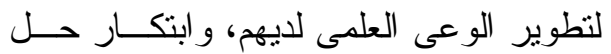

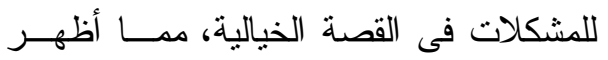
شكل من أثنكال الخيال العلىى الوجدانى لدى 
r- ملامح الــدور الــوظيفى لمؤســسات

رياض الأطفال فــى تنميــة الخيــال

$$
\text { والابداع العلمى للأطفال. }
$$

r- مشروع مقتر ح لتفعيل دور مؤسـسـات

رياض الأطفال فـى نتميـــة الخيــال

و الابداع العلمى لأطفال الروضة. لاطئ.

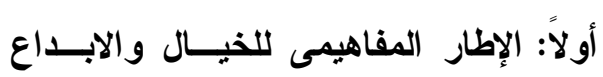

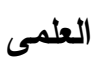

• Imagination مفهوم الخيال

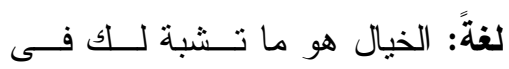

اليقظة و المنام من صورة ، و هو إحدى قوى

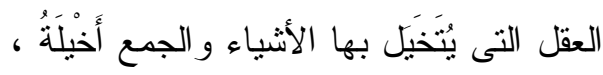

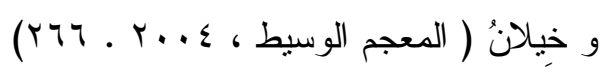

\section{وتعددت وتنوعت تعريفات الخيــال ومنهـــا}

$$
\text { ما يلإنى: }
$$

يعرفة " أبو سيف" بأنه : هو القــدرة

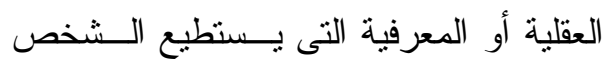

بو اسطتها تشكيل بعض عناصــر الحيــاه - ذهيـ

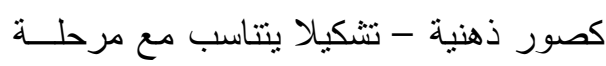

النمو العقلى التى يمر بها ، يتم الاحتفاظ بهذة دهنة

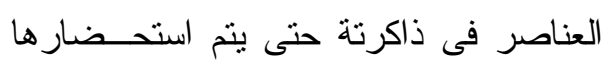

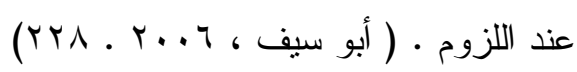

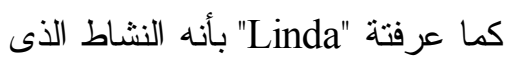

تمتزج فيه صور وخبرات وتوقعات الأزمنة

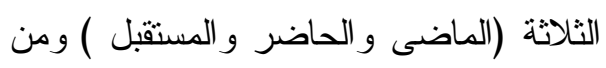

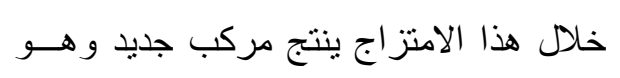

الجسمية و العقلية و النفسية و الاجتماعية، بمــــا

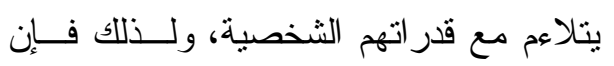

إعداد الطفل فى هذه المرحلة لمواجهة الحياه

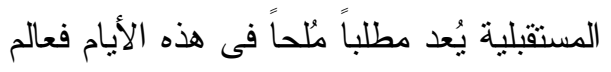

اليوم يتمبز بالكثير من التطورات و التغيرات

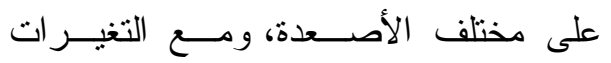

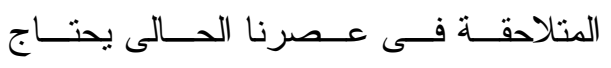

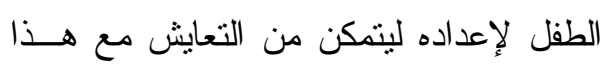

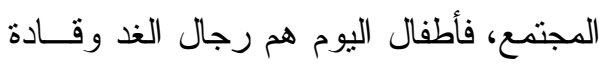
المستقبل.

وتو اصلاً مع هذا المعنى فإن التزبية

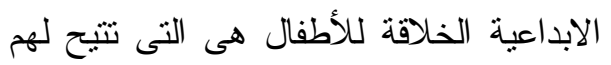

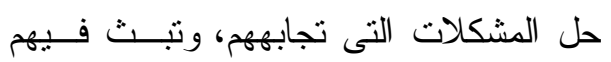

روح الاكتثاف العلمى مع عدم تقبل الأمور

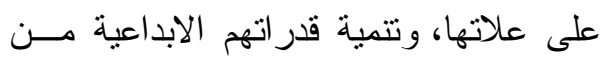
خلد الملاحظة، و التعامـل مـــع أســـئلتهم

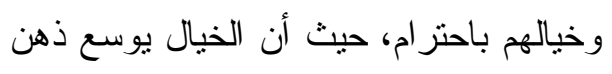

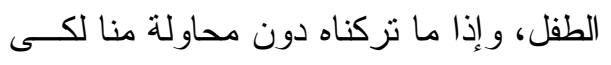

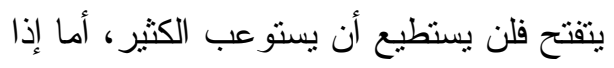
اتسع عقل الطفل أصبح من اليسير أن يُمــلأ

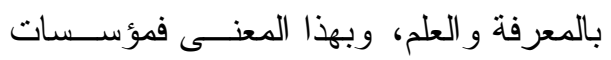

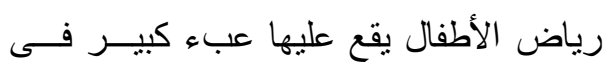
القيام بهذا الدور الهام لإعداد وتربية الأطفال

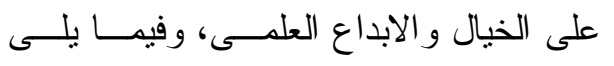
ستتناول الباحثة: ا - الإطـار المفــاهيمى للخيــال و الابـــــاع 
الكثف عن معنى الابداع فى اللغة العربيـــة

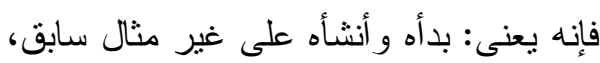

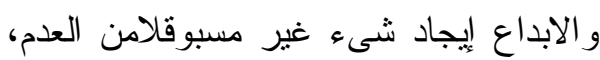

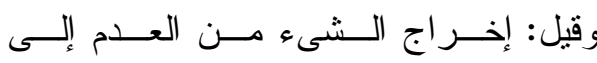
الوجود(المعجم الوسيط ، 1919 ـ ـ بـ). ويعرف هـــنيج ( Honig,2001)

الابداع بأنه التفكير المتشعب الذى يته ضضدن

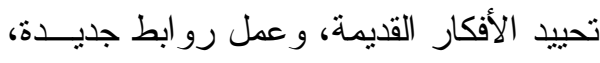
وتوسيع حدود المعرفــة، و إدخــال الأفكـار

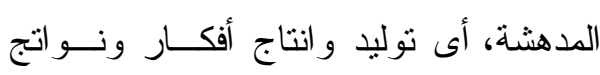
جديدة من خلال التفاعل الذهنى.

كما يعرفه جيلفورد Guilford بأنه

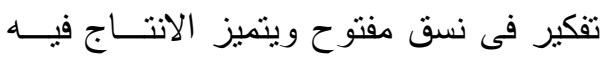

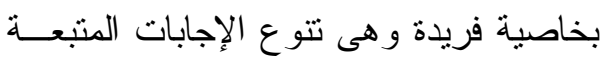

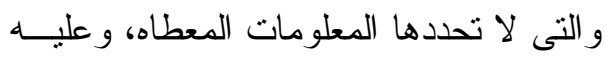
يذكر جيلفورد أن الابداع يتضمن عدة سمات

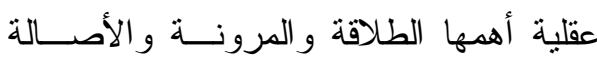

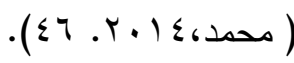

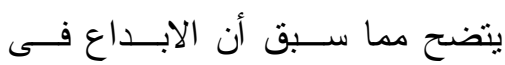

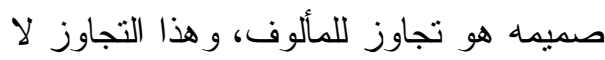
يمكن الوصول إليه إلا من خـــلد الاهتهــام

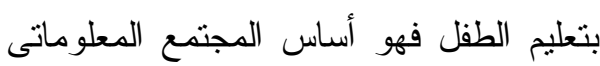
الجديد، فالأطفال هم قادة المستقبل فى إحداث

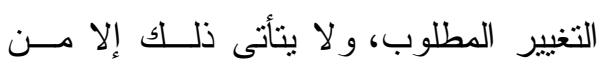

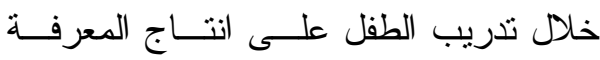

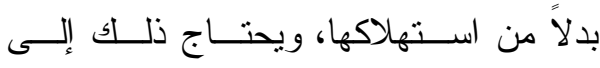

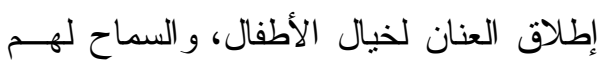

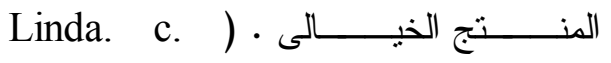

(Edwards, 1995.12

وتعرفة " محمد" بأنها : عملية عقليــة

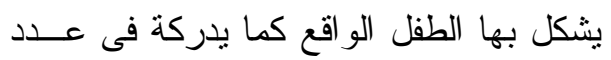
من الصور العقلية الحسية ، التى تتناسب مع لتع

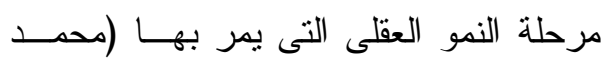
. ( IV. Y...)。

مما سبق يتضح أن الخيال هو قدرة

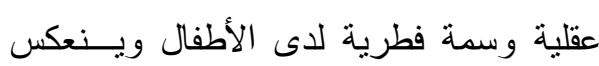

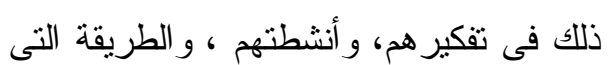

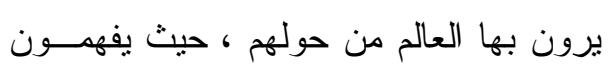

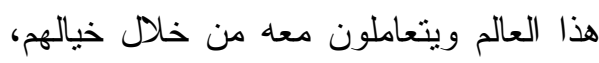

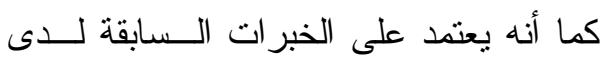
الطفل التى تمتزج بالحاضر و المستقبل فكلما كانت خبرات الطفل ثرية ومنتو عة كلما كان خياله مبدعاً. فالابداع هو مزيج من الخيال العلمى المرن الذى يعمل على تطوير فكرة قديمة أو هرئ

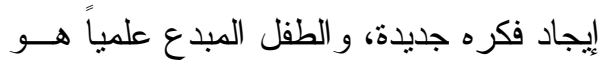

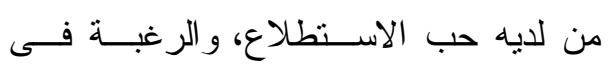
الاكتشاف و المعرفة للعالم المحيط به، بجانب لإنب

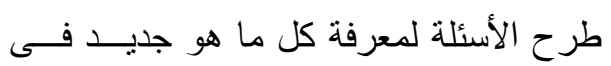

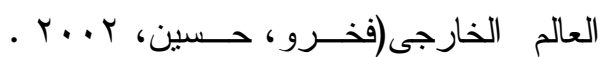
.$(74$ وتتعدد الآر اء وتختلف فـى تعريــف

معنى الابداع ومردود ذلك أنه ظاهرة انسانية

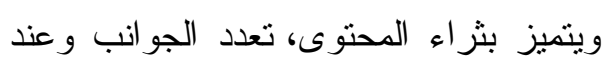


كما أن البيئة التعليمية والاجتماعيـة للطفل فى الروضة تؤثز فى الأبعاد المزاجية

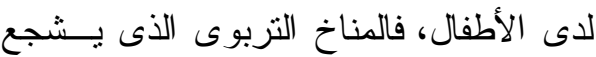

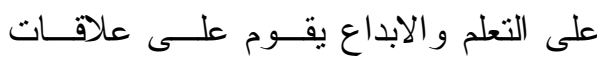

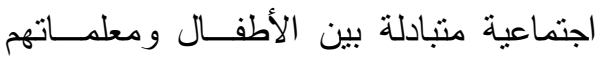

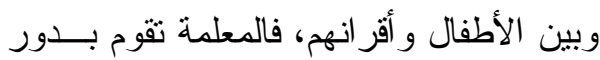

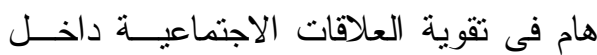
حجرة النشاط، وتشحذ طاقات الأطفال العقلية

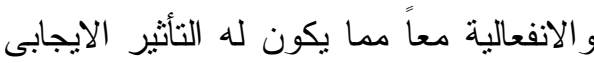

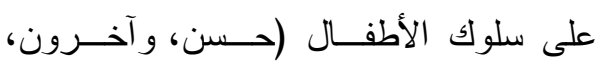
( I TO-ITt . r.)

ففى هذه البيئة بشعر الأطفال بحريسـة

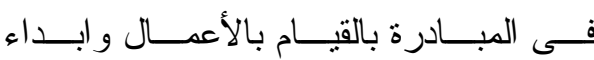
التساؤلات ومن جانب آخر ، فإن هذه البيئـــة

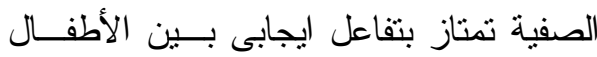
أنفسهم، وبتفاعـلـل ايجــابى بــين الأطفــال ومضمون المادة الدراسية، كما تمتاز بتشجيع التهاع

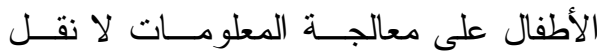
المعلومات وتلقيها، فتتاح الفرصة للأطفــال

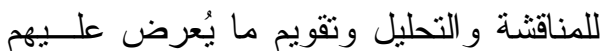

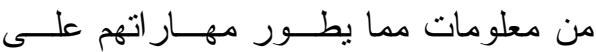

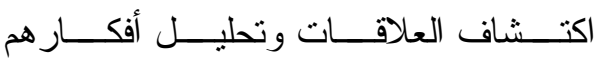
و افتز اضاتهم باستمر ار، بالإضافة إلى توفير

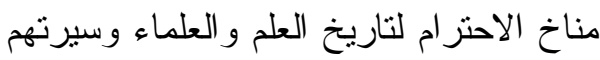

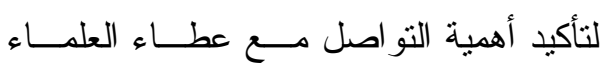
السابقين، و الإضافة عليه فى المستقبل مـنـ

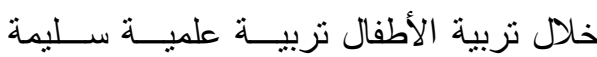

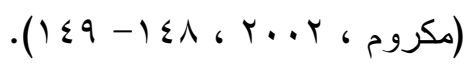

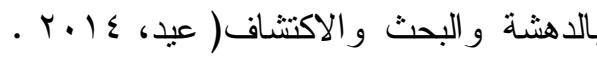

.$(1 \leq \varepsilon$

وبهذا المعنى فان الاهتمــام بتتميــة

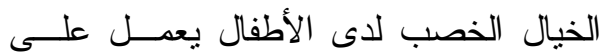
تتمية ابداعهم العلمى وخيالهم العلمى بـشكل كبير لإعدادهم لمواجهـة المـستقبل بكــل تحدياته المستمرة و المتطورة وفيما يلى سيتم

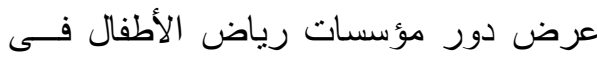

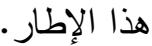

ثاتياً : ملامـح الدور الـــوظيفى لمؤسـسـات رياض الأطفــال فـــ تنميــة الخيــال

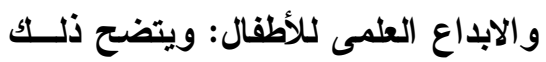

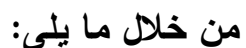

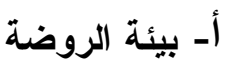

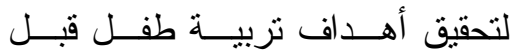
المدرسة لا بد من تتظيم حجرة النشاط بحيث

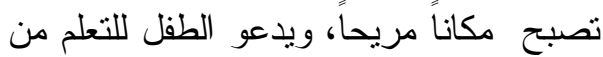

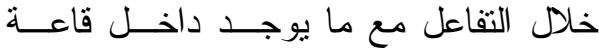
النشاط، و عادة تكون على شكل أركان تتبـــر دافعية الطفل للنشاط و اكتــــاب الخبــر ات، و الأركان التعليمية جزء مهم مــن العمليــة التزبوية الحديثة، فهى ترنكز علـى الــتعلم الذاتى للطفل حيث يتم مــن خلالهـــا تــوفير الخبر ات و المهار ات المطلوب مــن الطفــلـ اكتسابها، بحيث يحُث كل ركن تعليمى على

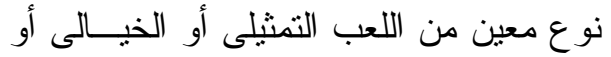

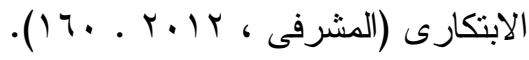


الطفل على مر احل نمو ها المختلفة، وتتــاقش

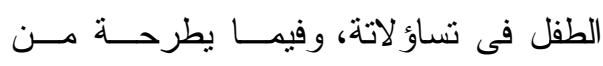

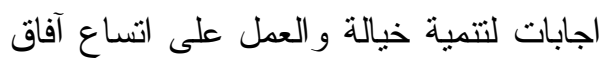
تفكيرة فيما حولة (عبد الــرحمن ، 9 . . ب . .$(10)$

من جانب آخر يُعد اهتمـــام المعلمــة

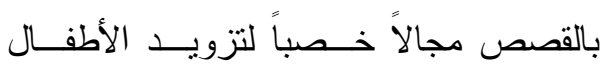
بالمفاهيم العلمية، وتوجيهـم للبحث العلمـى بـى الذى يقوم على فرض الفــروض، و اختبــــار

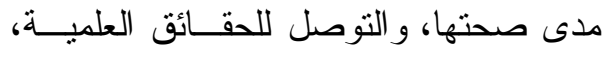

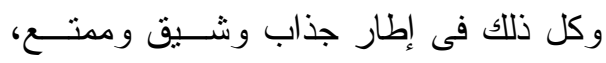
حيث تتضمن الحقائق و المعلومات عن النبات و الحيوان والمظاهر الطبيعية مما يعمل على

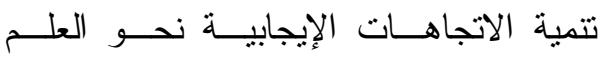
و العلماء، وإثارة اهتمام الطفل العلمى وخيالة

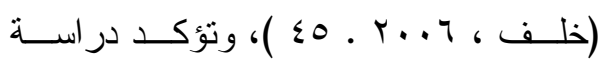
Laprise, Winrich, لابريس ، وينـــتش 2010) على أهمية استخدام أفــلام الخيــال العلمى عند تدريس العلوم، حيث تعتبـــر أداة

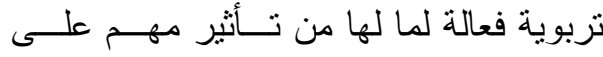

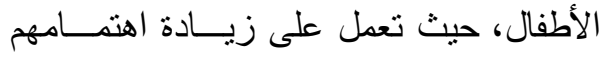
بدر اسة العلوم وتحفز هم وتعزز التفكير الناقد لديهم حول المفاهيم العلمية المختلفة. كما تؤكد در اســـة(توفيـق ، ع ا • r ) على استخدام الأنشطة العلمية الاستكـشافية التى تتيح للطفل فرص التجريــب و العمــل

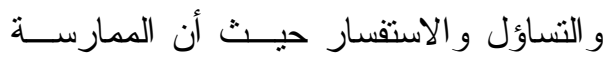

ب- معلمة الروضة وأدائها التعليمسى مــع

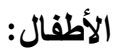

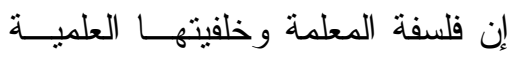

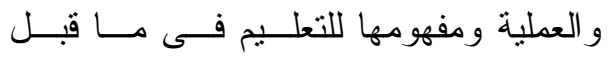
المدرسة وأهميتة تُشكل كلها عنصر اً أساسياً فى ديناميكية الموقف التعليمــى، فالمعلمـــة

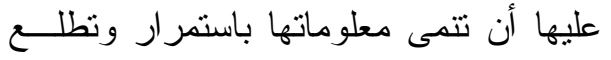

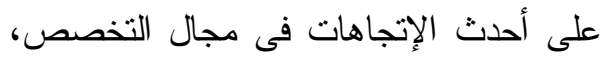
وتجرب ما تقر أ عنه من استر اتيجيات حديثة

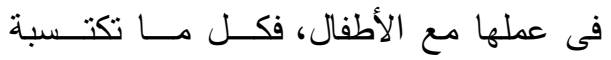

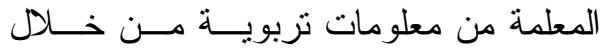

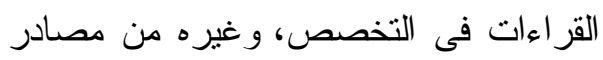

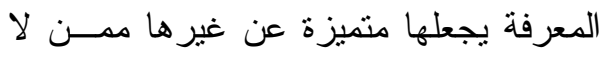

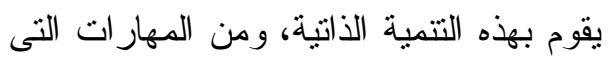
تحقق النمو المهنى المنشود: تنظيم رحسـلات للاستكثاف داخل وخارج الروضة، واثــارة

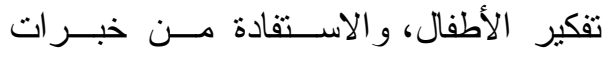

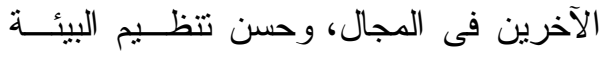

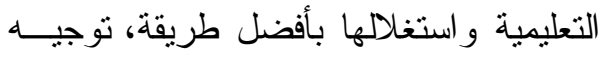

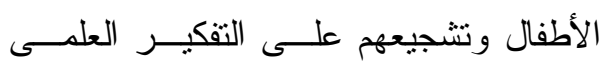

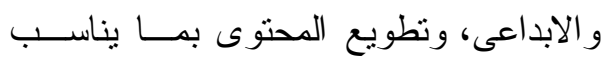

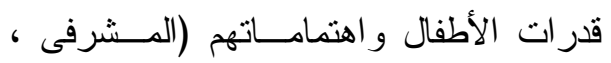

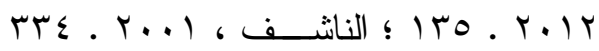
.

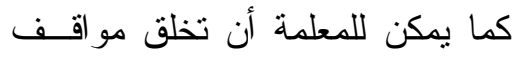

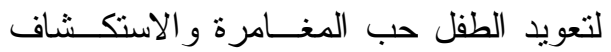

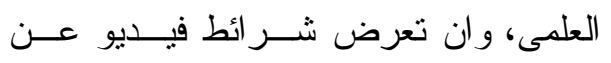

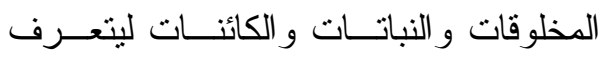


و المخترعين ، لعب الأدوار)، حيــث تقــوم

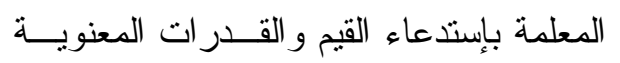

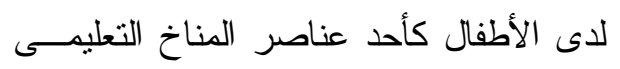

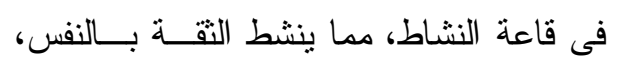

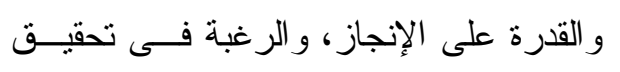
المنل الأعلى، و التعلق بالمستقبل.

جـ- المنــاخ التعليمــى والاســتراتيجيات المستخدمة فى قاعة النشاط

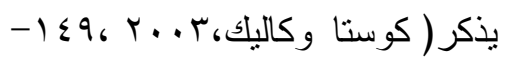

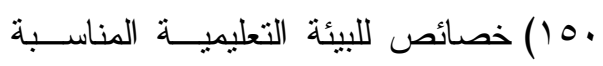
لتتمية الابداع لدى الأطفال، ومن ثم يسساعد ذللك على تتمية الخيال و الابداع العلمى لديهم وتتمنل فيما يلى:

- تشكيل وطرح أسئلة تعتمد على تحــدى فكر الأطفال وخيالهم.

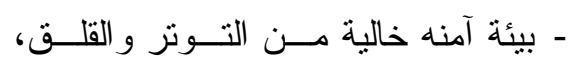
وداعمة للطفل عاطفياً.

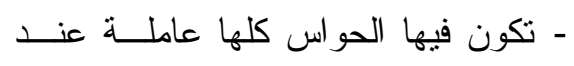

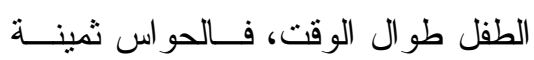

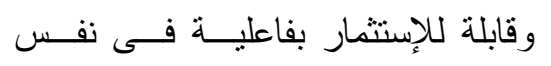

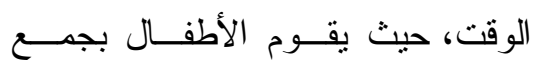
البيانات باستخدام الحو اس.

- المتعة و السعادة من أهم صفاتها، حيث

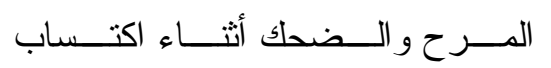
المعلومات.
المستمرة لهذه العادات منذ الــصغر تجعـل

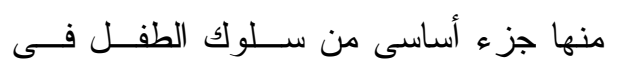

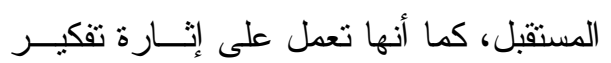
وخيال الطفل بشكل فعال.

بالإضافة إلى أهمية استخدام المعلمـــة

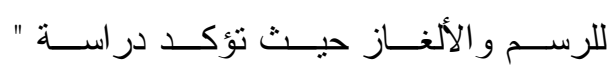
شييردسون" ( Shepardson and Britsch

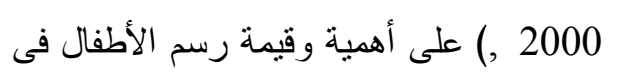

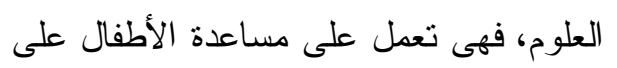

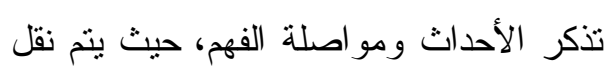
العلوم للأطفال من خلال رسومهم، كما تمثل الألغاز المصورة أحد الأنشطة المنضمنة فى لاطى

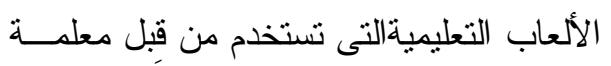
الروضة، وتشمل بعض المعلومات و الحقائق

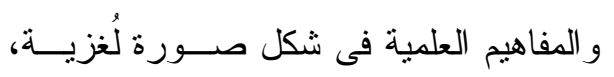
ويطلب من الأطفال الاستجابة لها و التفاعـلـ لئل معها، واستخدام الألغاز المصورة فى تدريس الاسن العلوم للأطفال بعمل على تحفيـز التفكيـــر

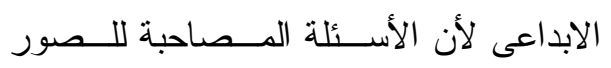

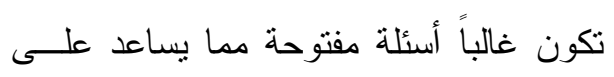

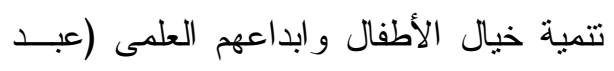
النبى، ( . . 1 . 17 ) ).

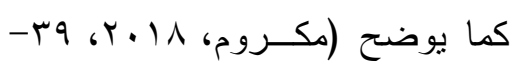

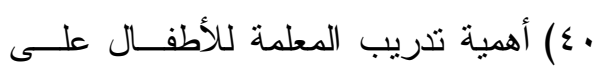

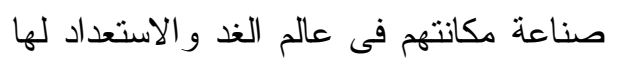
من خلال (صورة المتل الأعلى من العلماء 
للمجموعة الو احدة، ويطالبون بعمل مــشترك

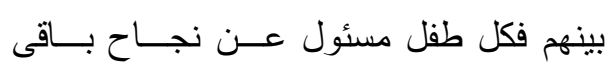

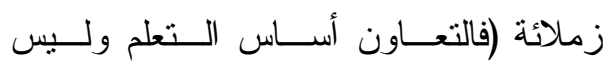
(النتافس). ؛. استراتيجية اســتخدام تـساؤلات مــن

$$
\text { نوعية ماذا يحدث لو؟ }
$$

يُعد التفكير التباعدى من أنواع التفكير

التى تتميز بالأصالة، وتتضمن انتاج أفكـار

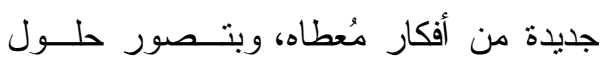

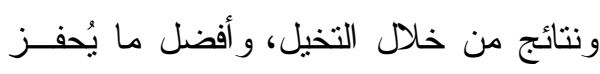

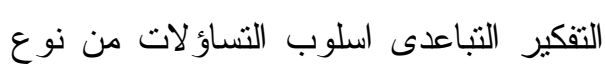

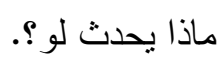
๑. استر اتيجية لعب الأدوار والتحدث مــع شخصيات غير مألمفة:

يقوم لعب الأدوار على نشاط الطفــلـ

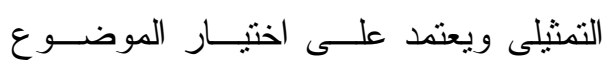
وتوزيع الأدوار على الأطفال من أجل تحقيق الأند

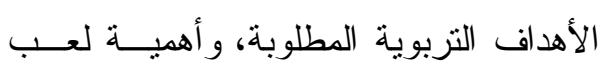

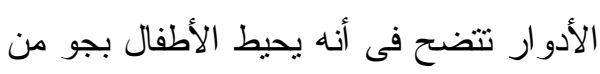

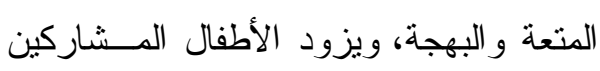

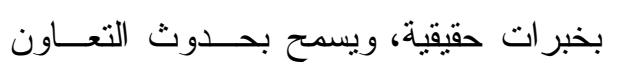
و التفاعل الاجتماعى بين الأطفال، ويقلل من وندئن الثعور بالتنافس.

7. استر اتيجية استكمال بدايات مطروحسة بـة

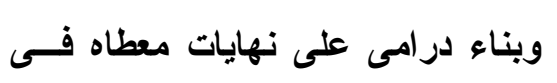

وتوجد مجموعة من الاســتر اتيجيات

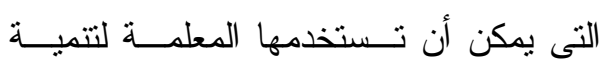

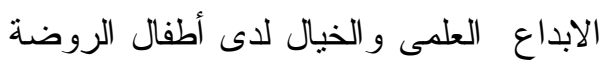

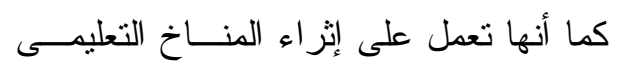

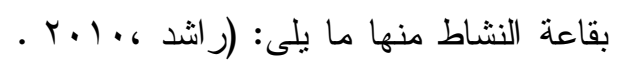
( $110-90$ ا ـ استرتيجية مشاهدة أفلام فيديو للخيال العلمى يتبعها جلسات سيمينار :

وفى هذه الاستر اتيجية تقوم المعلىـــة

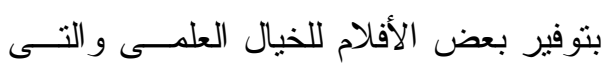

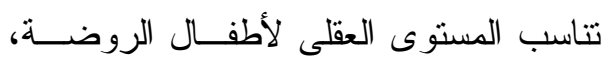

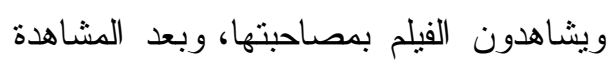
تتم المناقثة بين المعلمة والأطفال. r. استر اتيجية جلسات عصف ذهنى لإتتاج أفكار غير مألوفة:

وتنتخدم لدر اسة موضوع ما، ومسـن

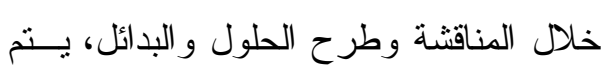

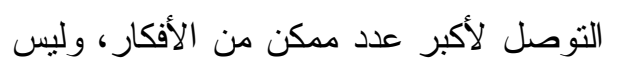
مناقشة الآر اء أو نقدها. r. استراتيجية التعلم التعاونى لإنتاج أفكار لقصص خيال علمى:

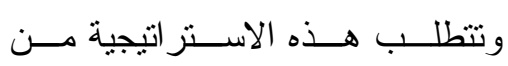
الأطفال أن يتدارسون المادة المتعلمة، وفــى

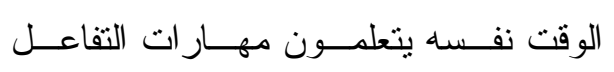

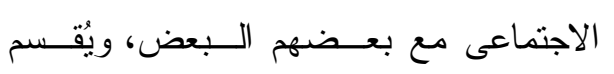

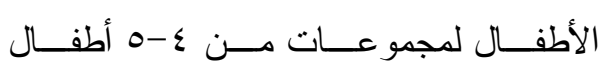


إن الأسرة من أهم الوسائط اللانظامية

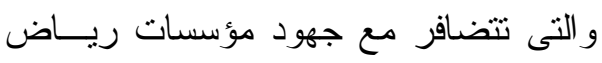

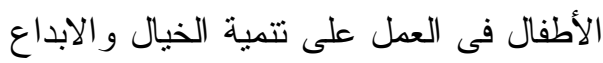

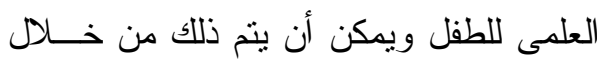

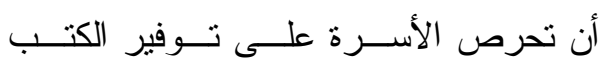

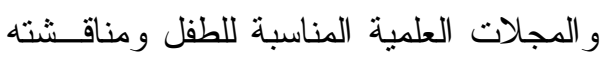
حولها، و انتقاءها للمناسب للطفل من وسـائل الإعلام المسموعة و المرئية، حيث أنها ليست وسيلة لتزويد الطفل بالمعلومــات و الأفكـار

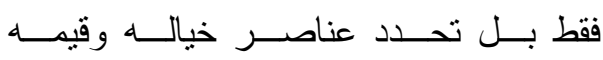

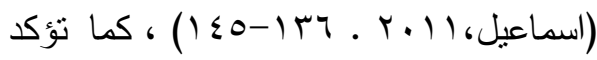

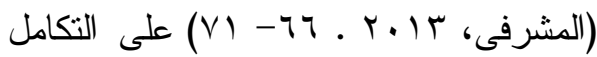
بين الروضة و الأسرة لتتمية الخيال و الابداع العلمى من خلال اسلوب المشروعات العلمية المشتركة بين الأسرة و الروضة.

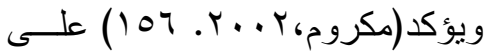

دور المتحف العلمى فى تقديم خدمات علمية متميزة ، حيث أن متـــاحف العلــوم تعتبـــر مركز اً هاماً للإهنمام العام بمظـــاهر التعلــيم غير الرسمى فى العلوم و التقنية، ويجب على متاحف العلوم كلما أمكنها أن توفر مجــالات

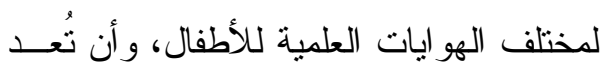

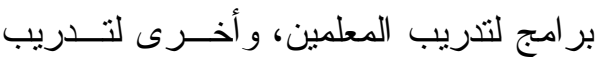
الأطفال و أولياء الأمور ، كما يجب أن تتـيح الفرص لتوفير التجارب و الخبر ات المباثـــرة التى تكمل الوسائل الأخرى كالقر اءة الخاصة
قصص خيــال علمـسى ، وتــتم هـــه الاستر اتيجية بطريقتين :

1-استكمال بدايات مطروحة فى قـصص خيال علمى :

وفيها تقدم المعلمة للأطفــال قـصة

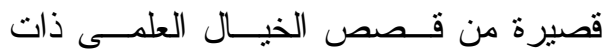
النهاية المفتوحة، أى لا تكون القصة كاملـــة

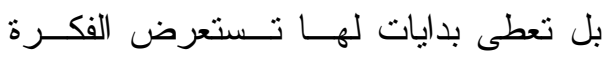
وبعض الثخـصـيات وخاصــة الرئيسـية، وبعض المو اقف و المشكلات التى قد تعترض ونس ترض البطل ثم تطلب من الأطفال محاولة استكمال

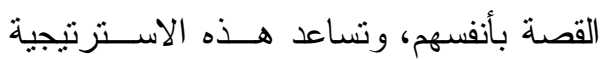
على نوليد معلومات و أفكار جديدة ومنتوعة،

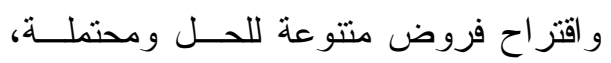

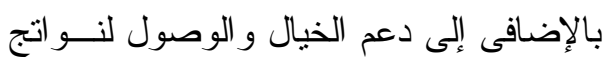

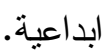

ץ-بناء درامى على نهايات مُعطـــاه فــى قصص خيال علمى: وهنا تقدم المعلمة نهاية قصة قصيرة وتطلب من الأطفال تخيل بداية القصة بحيث تتماشى مع هذه النهاية المعطاه وتتنتمل هذه

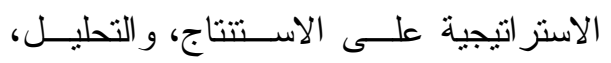

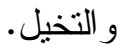

دـ - العو امل الداعـــة لمؤســسـات ريــاض

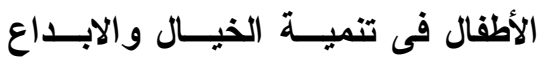
العلمى لأطفالها (الأسرة و المجتمع) 
التربوية المناسبة لنتمية الخيال و الابداع

$$
\text { العلمى للأطفال. }
$$

ثانياً: المعالم الرئيسية فى بنية المشروع لعهول تتحدد المعالم الرئيسية للمشروع المقترح من

$$
\text { خلال : ت }
$$

1- الإطار النظرى للتوعية بأهمية الخيال

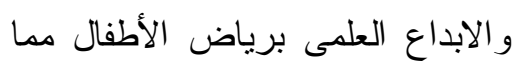

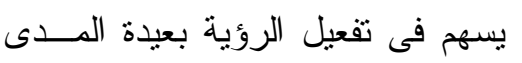

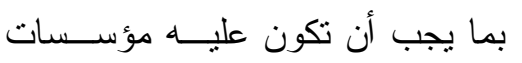

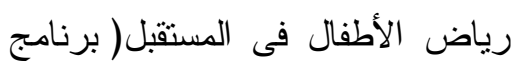

لتدريب المعلمات لدعم تتمية الخيــال

$$
\text { و الابداع العلمى للأطفال) }
$$

r- إعداد ورش عمل واختبارات مواقف

متتوعـــة للمــشاركة الفعالـــة بــين

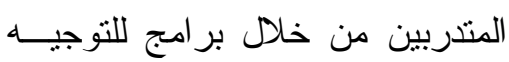

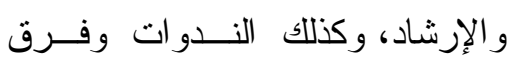

العمل المختلفة.

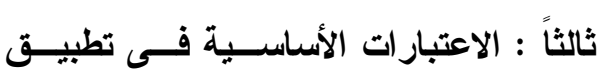

المشروع - (الناع

- إن الخيال و الابداع العلمى من المحسـاور

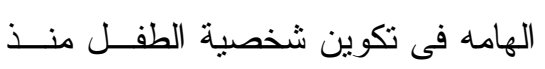

مرحلة رياض الأطفال، ومن ثم تكـــن

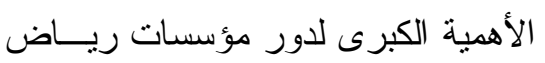

الأطفال فى إعداد الأطفال للمستقبل بكل مؤنسات

ما يحمله من تحديات وثـــورة معرفيــة
ووسائل الإعلام، أى التأكيد علــى العلاقـــة

$$
\text { بين(عَالم العِلم ، عالم الإنسان). }
$$

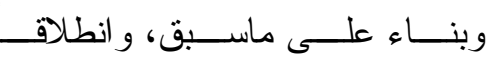

مما توصلت إليه الدراسة من أفكار و رؤى مانى ولطان

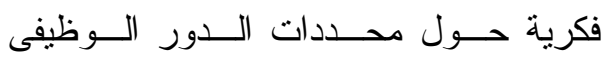

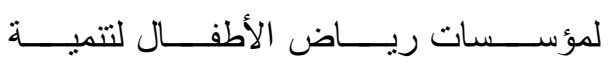

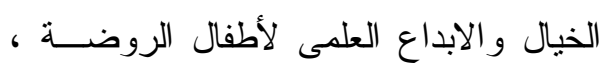

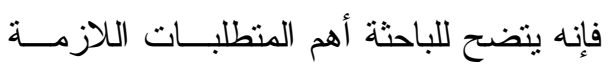

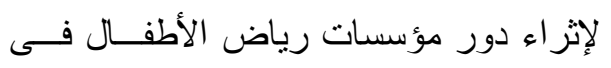

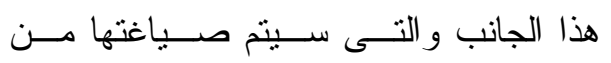

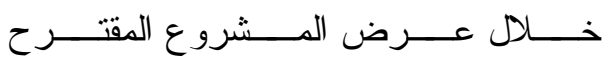
التالى :

أولاً : أهداف المشروع المقترح

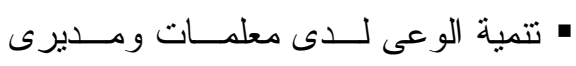

رياض الأطفال بأهمية استخدام الخيــال

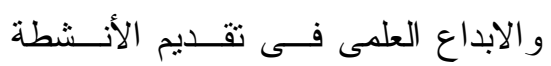

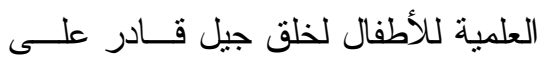

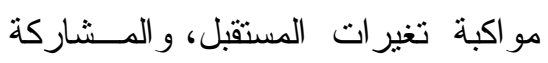

فيها.

- توفير مناخ تربوى داعم للعلم بمؤسسات

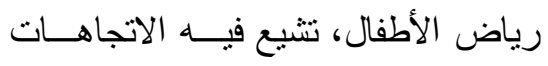

الإيجابية نحو العلم و العلماءو احتر امهم، لإنهان

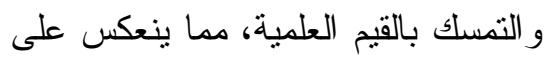

$$
\text { الأطفال بشكل ايجابى. }
$$

• إعداد وتأهيل معلمات رياض الأطفــال

تأهيلاً مناسباً يمكنهن من نقديم الأنشطة 
- ترسيخ ثقافة التتمية المهنية المـستدامة لدى معلمات رياض الأطفال،و الاهتمــام بالمعرفة العلمية المتجددة. • تتبنى وزارة التزبيـــة و التعلـــيم خطـــة استر اتيجية قومية لتتمية الخيال و الابداع العلمى للطفل المــصرى منـــذ مرحلـــة رياض الأطفال، حيث أن ذلك من شأنه إعداد جيل المستقبل القادر على إحــداث ومو اكبة التغير ات العالمية.

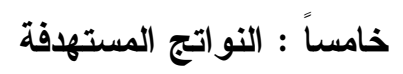
• الإرتقاء بالمستوى العلمى و الثقافى لدى

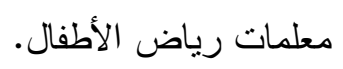
• صياغة برنامج تدريبى لمعلمات رياض

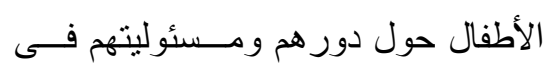

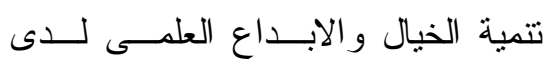
الأطفال، وقد روعى فى بناء البرنــامج التدرييى:

1 - أن يكون البرنامج التذريبى فى صورة حقائب تدريبية

r- أن تشتمل كل حقيبة تدرييية على الإطار

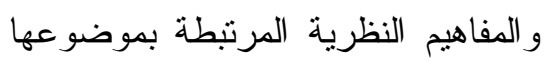

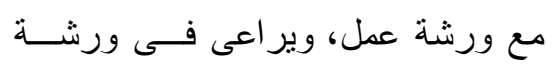
العملما يلى:

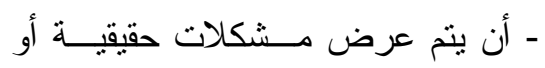
افتز اضية نرتبط بمو اقف حول كفـــاءة
• الحاجة إلى ضــرورة وجــود فلــسفة واضحة المعالم لتحقيق التتمية الـــليمة لخيال ابداع الطفل العلمى فــى مرحلــــة

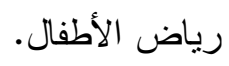

رابعاً : متطلبات تطبيق المشروع المقترح • عقــــدور ات وورش عمـلـ لمعلمــات رياض الأطفال حول التخطيط الابداعى

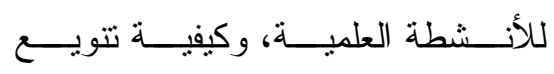
الاستر اتيجيات لتتمية الخيــال و الابـــــاع العلمى للطفل. • التأكيد على توفير الإثابة و التكريم اللازم

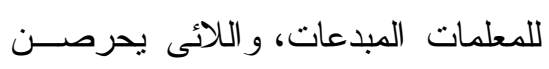

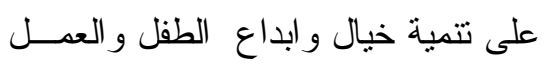
على استخدام وسائل التو اصل المختلفــــة

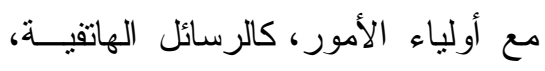
النشرات المطبو عة، تطبيقــات وســائل التواصل الاجتماعى، تقـــارير التقــويم الخاصة بمدى تقدم الطفل ومشاركتة فى

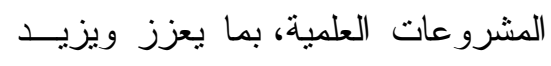
من التفاعل و التو اصــل بــين الأســـرة و الروضة فى تتمية الخيـال و الابـــداع العلمى للطفل. 
0- حسن، نبيل السيد ، العريثى، جبريل بن

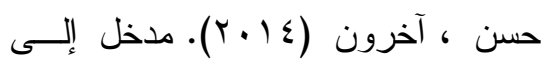

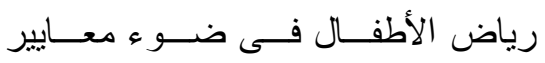

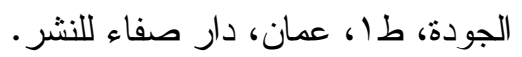

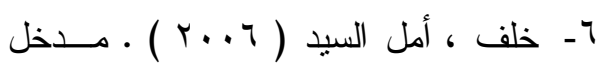
إلى رياض الأطفال ، القــاهرة ، عـــالم الكتب.

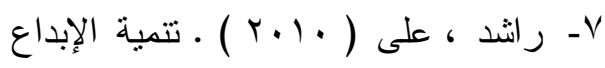

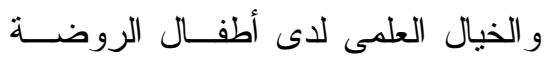

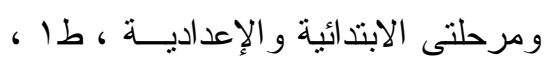
عمان - الأردن ، دار ديبونو للطباعـة ولئة و النشر.

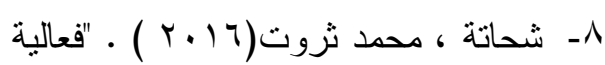
برنامج مقترح قائم على قصص الخيال

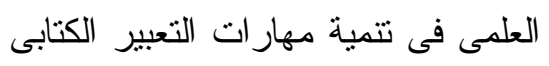

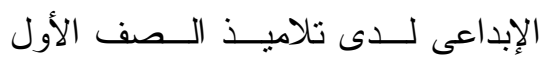
الإعدادى" ، رســالة ماجسـتير (غيــر

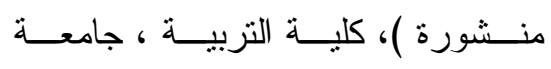
المنصورة.

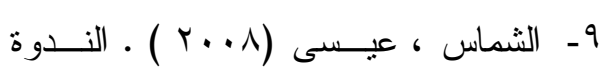
الأولى لكتاب الخيال العلمى فى الــوطن

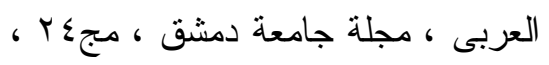
. I • 1-عبد الحميد ، شــاكر (1990 ) ) علـم

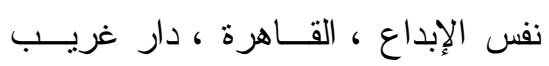
للنشر و التوزيع.
المعلمات فى استخدام أساليب لتتميــة الخيال والابداع العلمى لدى الأطفال، ومعايشة المتدربين للموقف و المشكلة،

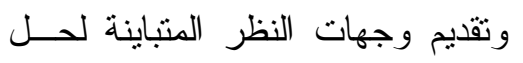
المشكلات المطروحة. - استخلاص نتائج الحوار و المناقثة فى نقاط أساســية تعبــر عـنـ الحــــول

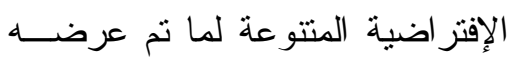
من مشكلات. 1- أبو سيف ، حسام أحمد محمد (T . . T )

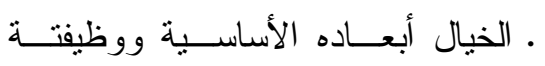

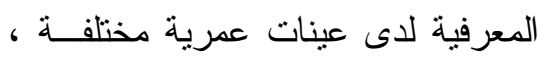

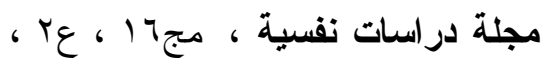

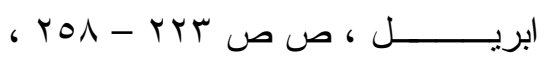
مصر.

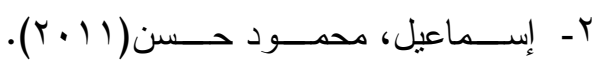
الإعلام وثقافة الطفل ، طا ، القاهرة ، دار الفكر العربى.

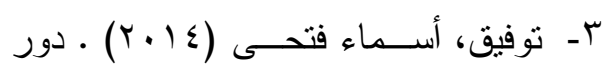

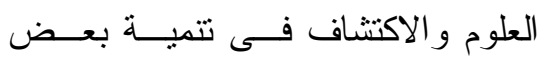

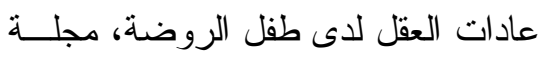

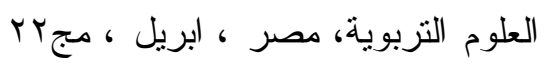
. $r V \wedge-r T_{1}$ ،

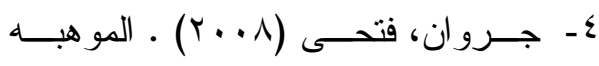

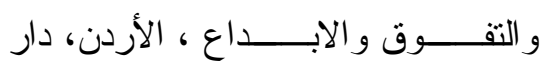
- الفكر 


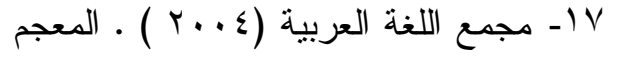

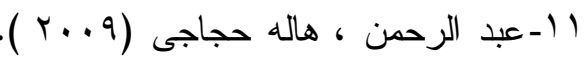

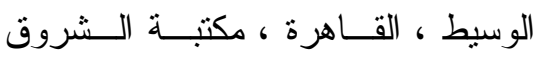

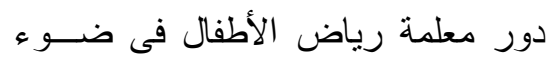

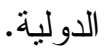

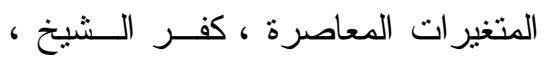

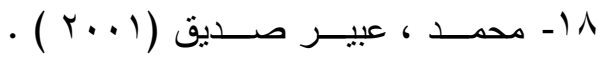

$$
\begin{aligned}
& \text { العلم و الإيمان للنشر والتوزيع. } \\
& \text { برنامج مفتوح لتتميــة خيــال الطفــل } \\
& \text { باستخدام أساليب عرض القصة ، رسالة } \\
& \text { ماجستير غير منشورة ، معهذ الدر اسات } \\
& \text { التزبوية ، جامعة القاهرة. }
\end{aligned}
$$

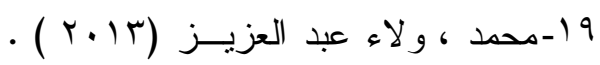

$$
\begin{aligned}
& \text { "برنامج لتتمية الخيال وعلاقته بمهار ات اتلاء }
\end{aligned}
$$

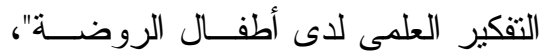

$$
\begin{aligned}
& \text { رسالة ماجستير (غير منشورة ) ، كلية } \\
& \text { رياض الأطفال، جامعة القاهرة. }
\end{aligned}
$$

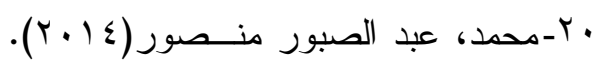

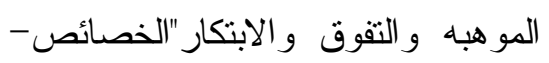

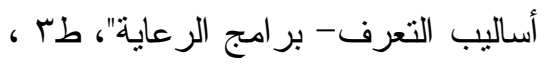

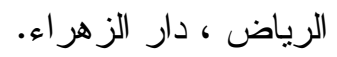

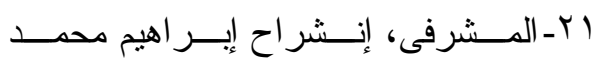

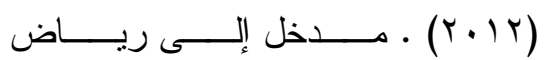

$$
\begin{aligned}
& \text { الأطفال،طץ ، الرياض، دار الزهر اء. }
\end{aligned}
$$

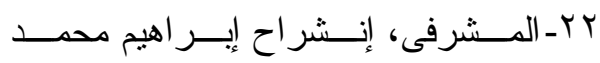

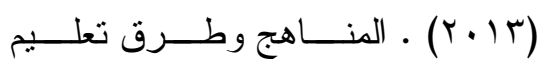

$$
\begin{aligned}
& \text { الأطفال ، الرياض، دار الزهر اء. }
\end{aligned}
$$

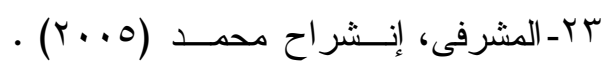

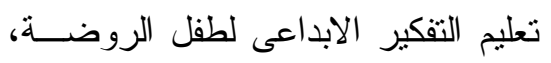

$$
\begin{aligned}
& \text { طا ، مصر ،الدار المصرية اللبنانية. }
\end{aligned}
$$

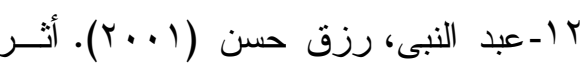

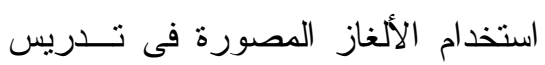

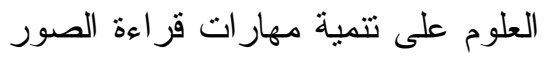

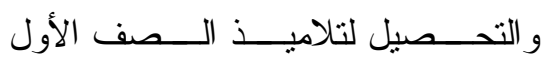

$$
\begin{aligned}
& \text { الاعدادى المتـــدين و المــتقلين عـن } \\
& \text { المجال الادراكى، مجلة التربية العلمية، }
\end{aligned}
$$

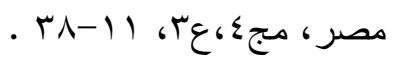

$$
\begin{aligned}
& \text { rا - عيد، محمد ابر اهيم (ع ا +r) ـ الابــداع }
\end{aligned}
$$

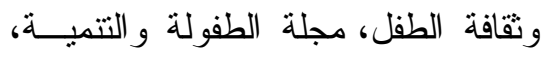

$$
\begin{aligned}
& \text {. } 17 \cdot-1 \leqslant r \text { ، }
\end{aligned}
$$

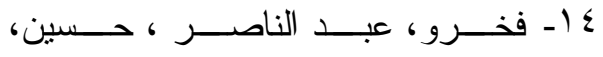

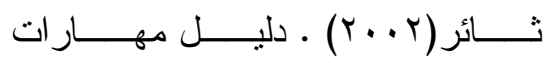

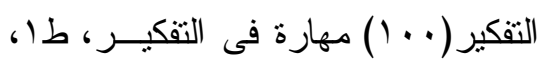

$$
\begin{aligned}
& \text { عمان، الأردن، جهينة للنشر و التوزيع. }
\end{aligned}
$$

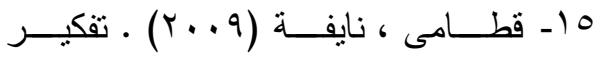

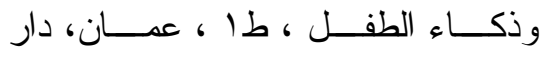

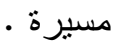

$$
\begin{aligned}
& 7 \text { (-كوستا ،آرثز ل، كاليك ، بينا (T . . r) . } \\
& \text { تقعيل و إثنعال عادات العقل ، ترجمـــة: } \\
& \text { مدارس الظهران الأهلية المملكة العربية }
\end{aligned}
$$

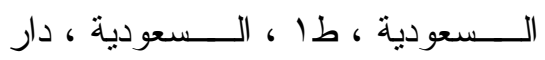

$$
\begin{aligned}
& \text { الكتاب التربوى للنشر و التوزيع. }
\end{aligned}
$$




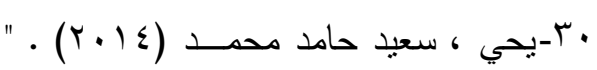

أثر تدريس وحدة فى العلوم باســتخدام

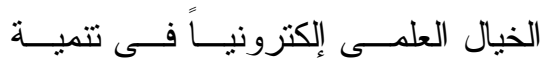

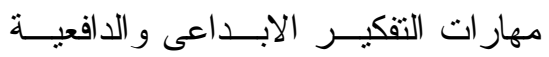

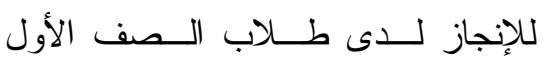

متوسط" ، مجلة در اسات عربيــة فـى لـى

التزبية وعلم الــنفس ، عه0 ، نـــوفمبر

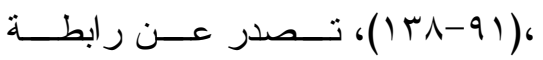

$$
\text { التزبويين العرب. }
$$

31-Fleer ， Marilyn ,(2013) :

Affective Imagination In

Science Education

Determining the Emotional

Nature of Scientific and

Technological Learning of

Young Children, Journal Of

\section{Research In Science}

Education, volume 43 , issue 5

, pp 2085-2101

32-Honig,A . (2001) . How to promote creative thinking.

Early

\section{Childhood}

Today,15(5),34-41.

33-Laprise, S.\& Winrich, C.(2010). The Impact Of
؟Y-مصطفى، إبــر اهيم ، الزيــات، أحمــــ

حسن، عبد القادر، حامد ، النجار ، محمد

عـــ(919 1) ـ المعجــم الوســيط ، القاهرة، دار الدعوة للنشر .

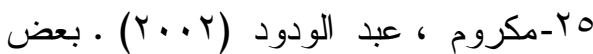

منطلبات تتمية القيم العلمية لدى طــلاب

المرحلة الثانوية ، مجلة مستقبل التزبية،

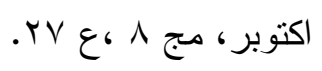

צr-مكروم ، عبد الودود (1) • ץ) • المدخل

القيمى فى مو اجهة القضايا و التحــديات

المعاصرة ، القاهرة، دار الفكر العربى.

TV T T T

العقلية ، طץ ، الاسكندرية، دار الفكـر

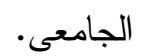

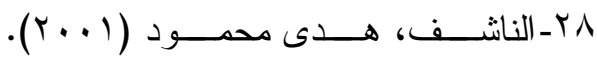

استر اتيجيات التعلم و التعليم فى الطفولــــة المبكرة ، القاهرة، دار الفكر العربى.

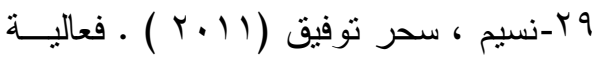

برنامج مقترح ييسط فكرة عمل بعـض

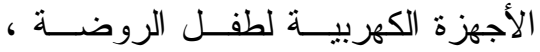
وينمى سلوكيات الأمان و السلامة لديــــ واتجاهه نحو تقدير جهود العلماء، مجلة الطفولة العربية ، المجلد (س ا ) ، العدد 
35-Shepard Son D.P, Britch S.J (2000):Children Science, Science and Children Nats, vol.(38),No(3) P 29-33.

36- Yan \& Leng (2005). An investigation of the relationship between the openendedness of activities and creativity of young children, university of New Orleans, United States.
Sience Fiction Films on Student In Science, Journal Of College Science Teaching, 40(2), PP 45-49 .

34-Linda.C. $\quad$ Edwards(1995): Affective Development \& The Creative Art , Merrill Publiehing Co., Columbus, P.12 . 